\title{
Interstitial Lung Disease Induced by Crizotinib in Non- Small-Cell Lung Cancer
}

\section{Doença Pulmonar Intersticial Associada ao Crizotinib no Tratamento de Cancro do Pulmão de Não Pequenas Células}

\author{
Andreia TERESO ${ }^{1}$, Luís CARRETO ${ }^{2}$, Manuela BAPTISTA ${ }^{1}$, Maria Amélia ALMEIDA ${ }^{3}$ \\ Acta Med Port 2019 Mar;32(3):236-239 - https://doi.org/10.20344/amp.9456
}

\section{ABSTRACT}

The treatment of advanced non-small-cell lung cancer shifted with the development of molecular-targeted therapies, like the tyrosine kinase inhibitors. One example of tyrosine kinase inhibitors is crizotinib, an anaplastic lymphoma tyrosine kinase inhibitor, which targets an echinoderm microtubule-associated protein-like-4-anaplastic lymphoma kinase gene fusion. This mutation is found in only $2 \%$ to $7 \%$ of non-small-cell lung cancer cases. Although these new therapies have shown promising results, the occurrence of interstitial lung disease as a side effect could be problematic. As the diagnosis of drug-related-interstitial lung disease is difficult to make, computed tomography is an important diagnostic tool. The recognition of computed tomography manifestations of tyrosine kinase inhibitors -induced interstitial lung disease is the key for an early recognition and management of this pulmonary toxicity. We aim to raise awareness of tyrosine kinase inhibitors -induced interstitial lung disease, by reporting the first case of a Portuguese patient treated with crizotinib for non-small-cell lung cancer who developed drug-induced interstitial lung disease.

Keywords: Carcinoma, Non-Small-Cell Lung/drug therapy; Crizotinib; Lung Diseases, Interstitial/chemically induced; Lung Diseases, Interstitial/diagnosis; Tomography, X-Ray Computed

\section{RESUMO}

O tratamento do carcinoma do pulmão de não pequenas células avançado mudou com o desenvolvimento de novas terapêuticas moleculares, tais como os inibidores da tirosina quinase. Um destes exemplos é o crizotinib que tem como alvo inibir a translocação do gene da quinase do linfoma, que se encontra presente em $2 \%$ a $7 \%$ dos casos de carcinoma do pulmão de não pequenas células. Apesar destes novos tratamentos mostrarem resultados promissores, a ocorrência de doença pulmonar intersticial como efeito secundário pode ser problemática. O diagnóstico de doença pulmonar intersticial associada ao tratamento é de difícil confirmação, o que tornou a tomografia computorizada uma importante ferramenta no diagnóstico. Pretendemos alertar para a doença pulmonar intersticial relacionada com os inibidores da tirosina quinase através da apresentação do primeiro caso de uma doente portuguesa tratada com crizotinib para carcinoma do pulmão de não pequenas células que desenvolveu doença pulmonar intersticial.

Palavras-chave: Carcinoma Pulmonar de Células não Pequenas/tratamento; Crizotinib; Doenças Pulmonares Intersticiais/diagnóstico; Doenças Pulmonares Intersticiais/induzidas quimicamente; Tomografia Computorizada

\section{INTRODUCTION}

Although new target therapies, like tyrosine kinase inhibitors (TKIs), have created a paradigm shift in the treatment of advanced non-small-cell lung cancer (NSCLC), the occurrence of severe adverse events remains problematic. ${ }^{1}$ One of the severe adverse events described was interstitial lung disease (ILD). ${ }^{2,3}$ ILD may appear during the initial treatment or years later, and the onset of symptons may be acute or insidious. Computed tomography (CT) is crucial to achieve an early diagnosis and to detect subtle parenchymal diseases. ${ }^{3}$

Crizotinib is an orally available small-molecule inhibitor of anaplastic lymphoma (ALK) tyrosine kinase, and showed promising results for treating stage IV NSCLC, with the fusion gene comprising portions of the ALK and the echinoderm microtubule-associated protein-like 4 (EML4). ${ }^{2}$ This fusion gene is expressed in $2 \%-7 \%$ of the NSCLC cases, predominantly in patients with reduced or no exposure to tobacco, and with adenocarcinoma..$^{1,4}$
We present a case of Crizotinib-induced ILD in a patient with stage IV NSCLC, where the diagnosis was prompted by a characteristic ground-glass opacity (GGO) finding in high-resolution computed tomography (HRCT) of the thorax.

\section{CASE REPORT}

A 40-year-old woman, with history of smoking (25 packyears), was diagnosed with stage IV lung adenocarcinoma with metastatic lesions. The tumor was tested for epidermal growth factor receptor (EGFR) mutation and ALK rearrangement, but it took one month for the results to be known. In this setting, she started cytotoxic chemotherapy with cystaplatin and pemetrexed. After one cycle of treatment she had progression and the fluorescence in situ hybridization analysis revealed the EML4-ALK gene fusion, so she initiated crizotinib (250 $\mathrm{mg}$, twice a day).

1. Serviço de Imagiologia. Hospital Prof Doutor Fernando da Fonseca. Amadora. Portugal.

2. Serviço de Pneumologia. Hospital Prof Doutor Fernando da Fonseca. Amadora. Portugal.

3. Unidade Autónoma de Oncologia. Hospital Prof Doutor Fernando Fonseca. Amadora. Portugal.

$\bowtie$ Autor correspondente: Andreia Tereso. andreia.tereso89@gmail.com

Recebido: 18 de julho de 2017 - Aceite: 06 de novembro de 2018 | Copyright (C) Ordem dos Médicos 2019 


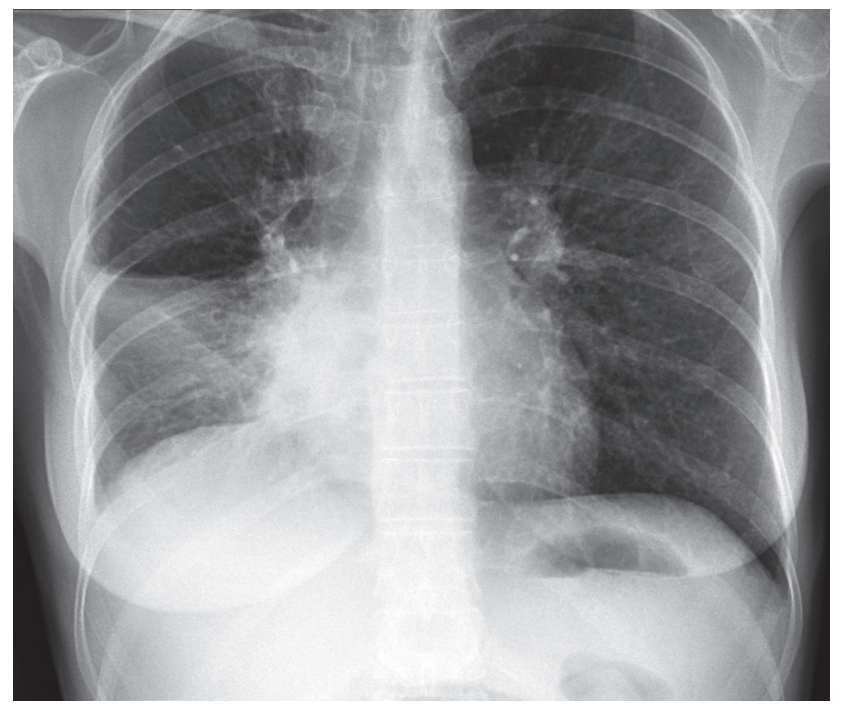

Figure 1 - Chest radiography: PA view: right lower zone opacification, limited superiorly by the small fissure, with silhouette sign with the right contour of the heart, which indicates its location in the medium lobe. The elevation of the right diaphragm and right shift of mediastinum suggests a right atelectasis. We also see discrete bilateral, regional opacities within reticular interstitial opacities.
After two months of crizotinib therapy, the patient presented with productive cough, fatigue, very high c-reactive protein serum level, and low oxygen saturation (87\%). For this reason, she was admitted to the respiratory department with the presumed diagnosis of pneumonia, and started empiric antibiotics. The chest radiography showed right lower zone opacification, within the medium lobe; a right atelectasis, suggested by the elevation of the right diaphragm, and the right shift of mediastinum; and findings related to lung cancer, such as regional opacities associated with reticular interstitial opacities (Fig. 1). Sputum and blood cultures and serologic tests were done. The cultures and the serology tests came negative, and the HRCT of the thorax showed: a crazy-paving pattern with bilateral and geographic GGO, well delimitated from the normal lung, and a fine reticular pattern related to an interlobular and intralobular septal thickening (Fig. 2). Meanwhile, the respiratory distress worsened, and she was admitted in the intensive care unit (ICU).

A crizotinib-induced ILD was assumed (grade 4 based on CTCAE V4). ${ }^{5}$ Crizotinib was immediately discontinued, and corticosteroids were initiated. After four days in ICU, she showed clinical and radiological improvement (Fig. 3).
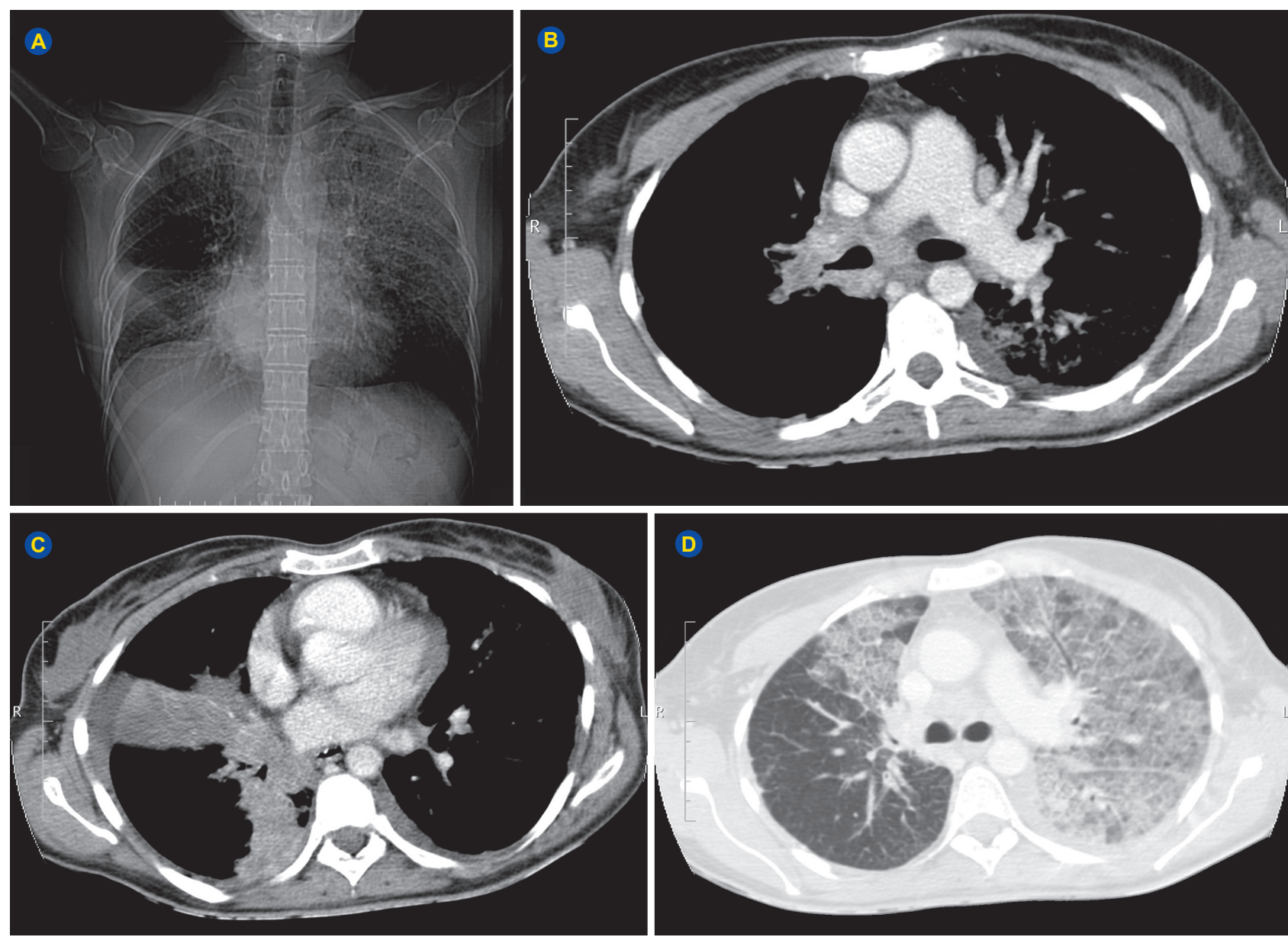

Figure 2 - HRCT of the thorax: (A) the bilateral reticular interstitial opacities are more pronounced; $(B)$ and $(\mathrm{C})$ findings related to the tumor: right-lower-lobe irregular and heterogeneous mass, that enhances after contrast administration; right hilar and mediastinal enlarged lymph nodes; right medium lobe atelectasis is seen, which may be related to obstructive pneumonitis; (D) bilateral, regional ground-glass opacities in association with interlobular and intralobular septal thickening, simulating a crazy-paving pattern. These findings are related with the initiation of crizotinib. 

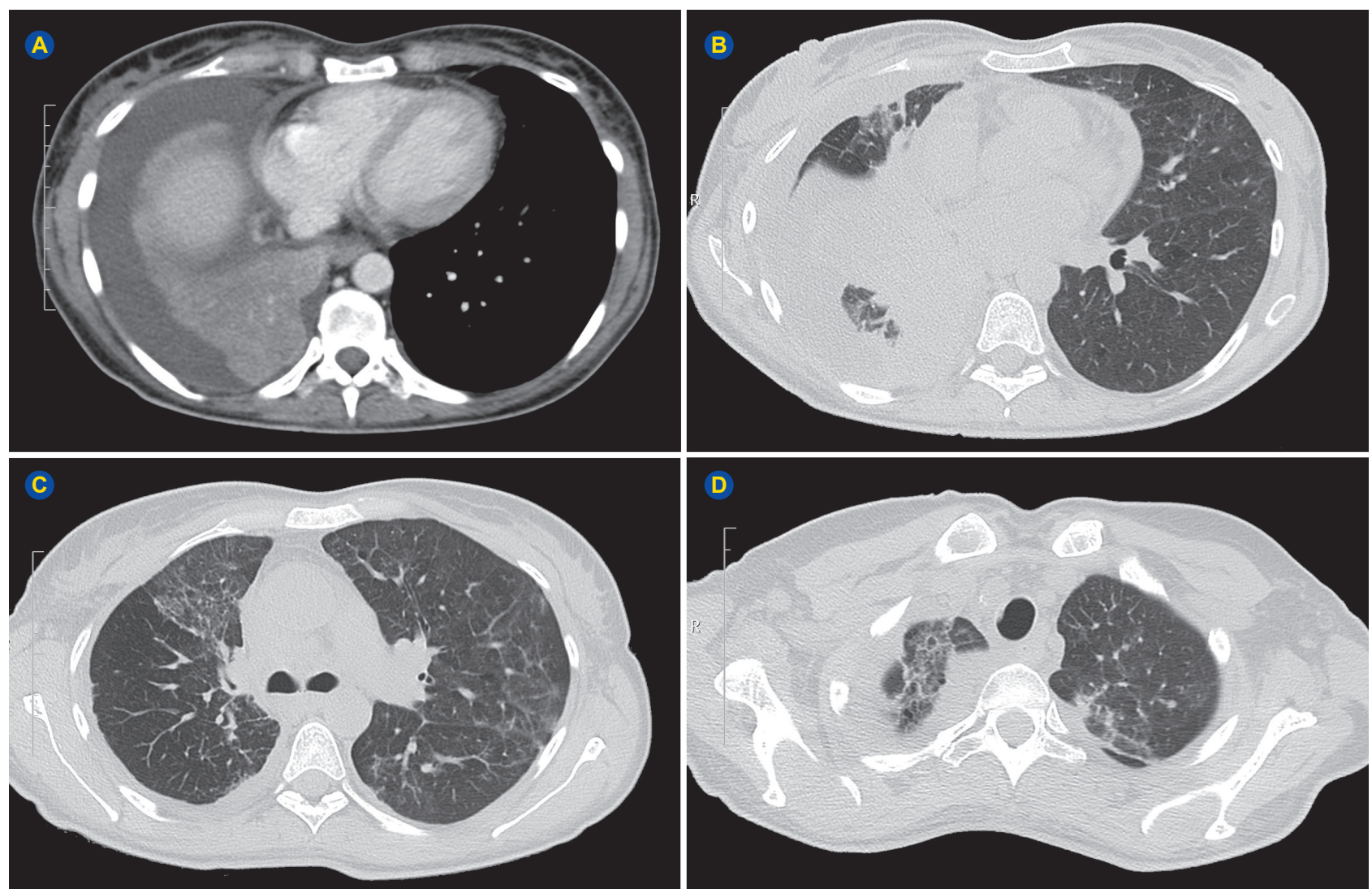

Figure 3 - HRCT of the thorax two weeks after crizotinib discontinuation: (A) there is progression of the tumor: growth of the right lower lobe opacification and new right pleural effusion; (B), (C) and (D) we can partial see almost total remission of the bilateral ground-glass opacities that were seen in the previous scan; there are some discrete reticular opacities and right pleural effusion that extends to right upper lobe.

Two weeks later, she underwent another HRCT of the thorax that showed partial response, with few ground-glass opacities.

With the discontinuation of Crizotinib, the disease progressed and she died six months after the initial lung cancer diagnosis.

\section{DISCUSSION}

The ILD related to TKIs used in advanced NSCLC treatment has already been studied and recognized. Crizotinibinduced ILD is considered a rare event, ${ }^{6}$ however, nowadays, there are more cases of Crizotinib-induced ILD reported, most of them in Asian patients with no related smoking exposure. . $7-12^{-12}$

Cough, fever and dyspnea may be present in patients with advanced NSCLC treated with TKIs, like in our case, but are usually non-specific. ${ }^{3}$ In addition, the onset of pulmonary complications is unpredictable and there have been some life-threatening cases. ${ }^{3}$ In this setting, CT is an important diagnostic tool, and the recognition of TKIs-induced ILD imaging features leads to an early diagnosis, and the correct management of these patients. ${ }^{4}$

In order to understand the CT manifestations of TKIsinduced ILD, we shall divide the pathogenic process between acute and chronic mechanisms. Usually, in the acute process, a diffuse alveolar damage is the histopathologic finding. ${ }^{3}$ On the contrary, the inappropriate regeneration of the injured epithelium leads to the stimulation of fibroblasts in the chronic process. ${ }^{3}$

The evaluation of drug-induced ILD CT features should include the distribution and the pattern of parenchymal lesions, such as interlobular septal thickening, honeycombing, ground-glass opacities (GGO), reticular lesions, traction bronchiectasis, and small centrilobular nodules. Usually these lesions appear with a patchy and bilateral distribution, and generally reflect the underlying histopathological process. ${ }^{13}$

Drug-induced ILD can present as diffuse alveolar damage (DAD), nonspecific interstitial pneumonia (NSIP), bronchiolitis obliterans organizing pneumonia (BOOP), eosinophilic pneumonia, obliterative bronchiolitis, pulmonary hemorrhage, and edema. ${ }^{13}$ Regarding TKI's-induced ILD classification, Min $\mathrm{JH}$ et al suggest six categories: DAD or acute interstitial pneumonia; bronchiolitis obliterans; BOOP; hypersensitivity pneumonia; NSIP; and UIP. ${ }^{3}$

DAD is the most common manifestation of drug-induced ILD, resulting from necrosis of endothelial cells, and type II pneumocytes. ${ }^{13}$ In terms of histopathology, DAD can be divided into acute, and chronic phases: the acute phase often appears at the first week of lung injury; the chronic and reparative phase, typically occurs after $1-2$ weeks. ${ }^{13}$ The patients usually present with dyspnea, cough, and 
fever. The chest $x$-ray shows bilateral heterogeneous opacities, commonly in the mid and lower lung, that progress to diffuse opacification. ${ }^{13}$ On HRCT, the early phases of DAD manifest as scattered or diffuse bilateral areas of GGO, and regions of consolidation involving the dependent lung regions. ${ }^{15,16}$ Some patchy areas of bilateral GGO in association with some lung sparing areas produce a geographical appearance. Confluent areas of GGO in association with reticular opacities result in a crazy-paving pattern. ${ }^{14}$, In the advanced phases, HRCT shows progressive fibrosis, with architectural distortion, and honeycombing. ${ }^{13}$ Our patient's HRCT showed typical findings of DAD (Figs. 2 and 3).

Any chemotherapy agent can be associated with overlapping CT patterns. Therefore, the clinician and the radiologist rely on the exclusion of other potential causes, and on the relationship between the onset of lung injury and the drug to make the correct diagnosis of TKI-induced ILD.

\section{PROTECTION OF HUMANS AND ANIMALS}

The authors declare that the procedures were followed

\section{REFERENCES}

1. Créquit $P$, Wislez M, Feith JF, Rosensztajn N, Jabot L, Friard S, et al. Crizotinib associated with ground-glass opacity predominant pattern interstitial lung disease, a retrospective observational cohort study with a systematic literature review. J Thorac Oncol. 2015;10:1148-55.

2. Soda M, Choi YL, Enomoto M, Takada S, Yamashita Y, Ishikawa S, et al. Identification of the transforming EML4- ALK fusion gene in non-smallcell lung cancer. Nature. 2007;448:561-6.

3. U.S. Food and Drug Administration. [FDA homepage] Label approved on 11/20/2013 (PDF) for XALKORI, NDA no. 202570. Reference ID: 3410361, para 5.2, p. 4. [accessed 2015 Feb 2]. Available from: http:// www.accessdata.fda.gov/drug- satfda_docs/label/2013/202570s006lbl. pdf.

4. Min JH, Lee HY, Lim H, Ahn MJ, Park K, Chung MP, et al. Drug-induced interstitial lung disease in tyrosine kinase inhibitor therapy for nonsmall cell lung cancer: a review on current insight. Cancer Chemother Pharmacol. 2011;68:1099-109.

5. U.S. Department of Health and Human Services. Common Terminology Criteria for Adverse Events (CTCAE). 2009. [accessed 2015 Feb 20]. Available from: https://www.eortc.be/services/doc/ctc/ CTCAE 4.03 2010-06-14_QuickReference 5x7.pdf.

6. Kwak EL, Bang YJ, Camidge DR, Shaw AT, Solomon B, Maki RG, et al. Anaplastic lymphoma kinase inhibition in non-small-cell lung cancer. $\mathrm{N}$ Engl J Med. 2010;363:1693-703.

7. Solomon B, Varella-Garcia M, Camidge DR. ALK gene rearrangements: a new therapeutic target in a molecularly defined subset of non-small cell lung cancer. J Thorac Oncol. 2009;4:1450-4.

8. Camidge DR, Bang YJ, Kwak EL, Lafrate AJ, Varella-Garcia M, Fox SB, according to the regulations established by the Clinical Research and Ethics Committee and to the Helsinki Declaration of the World Medical Association.

\section{DATA CONFIDENTIALITY}

The authors declare having followed the protocols in use at their working center regarding patients' data publication.

\section{PATIENT CONSENT \\ Obtained.}

\section{CONFLICTS OF INTEREST}

All authors report no conflict of interest.

\section{FUNDING SOURCES}

This research received no specific grant from any funding agency in the public, commercial, or not-for-profit sectors.

et al. Activity and safety of crizotinib in patients with ALK-positive nonsmall-cell lung cancer: Updated results from a phase 1 study. Lancet Oncol. 2012;13:1011-9.

9. Tamiya A, Okamoto I, Miyazaki M, Shimizu S, Kitaichi M, Nakagawa K. Severe acute interstitial lung disease after crizotinib therapy in a patient with EML4-ALK-positive non-small-cell lung cancer. J Clin Oncol. 2013;31:e15-7.

10. Yanagisawa $S$, Inoue $A$, Koarai $A$, Ono $M$, Tamai $T$, Ichinose $M$. Successful crizotinib retreatment after crizotinib-induced interstitial lung disease. J Thorac Oncol. 2013;8:e73-4.

11. Maka VV, Krishnaswamy UM, Kumar NA, Chitrapur R, Kilara N. Acute interstitial lung disease in a patient with anaplastic lymphoma kinasepositive non-small- cell lung cancer after crizotinib therapy. Oxf Med Case Reports. 2014;2014:11-2

12. Watanabe N, Nakahara $\mathrm{Y}$, Taniguchi H, Kimura T, Kondoh $\mathrm{Y}$, Kataoka K, et al. Crizotinib-induced acute interstitial lung disease in a patient with EML4-ALK positive non-small cell lung cancer and chronic interstitial pneumonia. Acta Oncol. 2014;53:158-60.

13. Rossi SE, Erasmus JJ, McAdams P, Sporn TA, Goodman PC. Pulmonary drug toxicity: radiologic and pathologic manifestations. RadioGraphics. 2000;20:1245-59.

14. Tagliabue M, Casella T, Zincone G, Fumagalli R, Salvini E. CT and chest radiography in the evaluation of adult respiratory distress syndrome. Acta Radiol. 1994;35:230-4.

15. Hansell D, Bankier A, MacMahon H, McLoud T, Muller N, Remy J. Fleischner Society: glossary of terms for thoracic imaging. Radiology. 2008;246:697-722 